\title{
IS THERE EVIDENCE OF A WAGE PENALTY TO FEMALE PART-TIME EMPLOYMENT IN SOUTH AFRICA?
}

\author{
DORRIT POSEL* AND COLETTE MULLER ${ }^{\dagger \neq}$
}

\begin{abstract}
In this paper, we investigate female part-time employment in South Africa. Using household survey data for South Africa from 1995 to 2004, we show that women are over-represented in part-time employment, and that the growth in part-time work has been an important feature of the feminisation of the labour force. In contrast to many studies of part-time work in other countries, however, we find evidence of a significant wage premium to female part-time employment. The premium is also robust to fixed effects estimations using Labour Force Survey panel data from 2001 to 2004, where controlling for unobservable differences increases its size. The premium persists with different hourly thresholds defining part-time employment and when we account for possible reporting errors in hours worked.
\end{abstract}

JEL Classification: J21, J22, J31

Keywords: Part-time employment; working hours; South Africa; protective labour legislation

\section{INTRODUCTION}

Three findings common to the international literature on part-time employment are that most people who work part-time are women; the increase in part-time employment has been an important part of women's growing share of employment more generally; and controlling for a range of individual and job characteristics, hourly earnings are lower in part-time wage employment than they would be if employment was full-time (Long and Jones, 1981; Ermisch and Wright, 1993; Rosenfeld and Birkelund, 1995; Bardasi and Gornick, 2000; Manning and Robinson, 2004).

In this paper we investigate female part-time employment in South Africa. We use nationally representative, cross-sectional household survey data to show that women are over-represented in part-time work, and that with the feminisation of the labour force from 1995 to 2004, female part-time employment has grown considerably. However, when we control for a range of measurable characteristics in the wage equation, we find no evidence of an hourly wage penalty to female part-time employment. Rather, there is a significant wage premium. The size of this premium increases considerably when we control also for the nature of employment, suggesting that part of the estimated premium reflects the lack of security and fewer benefits associated with part-time work.

Differences in unmeasured attributes of part-time and full-time workers may be introducing bias in the wage estimations. However, if part-time employment is associated

\footnotetext{
* Corresponding author: School of Development Studies, University of KwaZulu-Natal, Republic of South Africa (posel@ukzn.ac.za)

$\dagger$ School of Economics and Finance, University of KwaZulu-Natal, Republic of South Africa (mullerc2@ukzn.ac.za)

‡ We gratefully acknowledge the financial support of Economic Research Southern Africa (ERSA) in the completion of this study.
} 
with lower unmeasured skills or labour market attributes, then we would expect the nature of the bias to reinforce rather than reduce the premium to part-time employment. We re-estimate our earnings equations using available panel data in South Africa, the Labour Force Panel (2001-2004), and we find that as expected, the size of the estimated premium increases when we control for individual fixed effects.

We further test the robustness of our results to the definition of part-time employment and to reporting errors in working hours. We show that the premium remains robust to raising the threshold for part-time employment from 34 to 39 hours a week, as well as to lowering it to 28 hours worked. Furthermore, although the over- or under-reporting of working hours by full-time and part-time workers, respectively, may bias the premium upwards, the premium remains robust and significant when we account for possible reporting errors in hours worked.

In the next section, we outline key questions and findings from the international literature on part-time employment. In section 3, we discuss the data and the definition of part-time employment used in this study, we describe changes in part-time employment in South Africa, and we compare individual and labour market characteristics of our samples of women with part-time and full-time employment. We also review protective labour legislation in South Africa, and its application to part-time and full-time employment. In section 4, we elaborate on the estimation methods used to compare returns to part-time and full-time employment, and present the key results. In the conclusion we briefly review the findings of our study.

\section{CONTEXT}

Part-time employment typically is work performed by women, providing women with a means to reconcile paid work and household work (and particularly the care of children). In many industrialised countries, the growth in part-time employment, notably through the expansion in the service sector, has been an integral component of women's increasing share of total employment (Rosenfeld and Birkelund, 1995; Bardasi and Gornick, 2000).

A key question that dominates the literature on part-time employment concerns whether women are penalised for working part time. There are a number of reasons why a part-time wage penalty may be expected. First, employers incur fixed labour costs of hiring (associated with recruiting and training workers for example), which are proportional to the number of workers rather than the number of hours worked. This therefore increases the average hourly costs of part-time jobs compared with fulltime jobs (Hirsch, 2004; Rodgers, 2004). Second, part-time workers may have more limited mobility if they are secondary breadwinners in the household. This makes it possible for employers to practice monopsonistic discrimination, paying lower wages for part-time employment (Ermisch and Wright, 1993; Hardoy and Schøne, 2006). Third, employers may be reluctant to provide training to part-time workers whose labour force attachment is expected to be weaker than that of full-time workers (Owen, 1978).

Studies have tested for a wage gap between full-time and part-time employment estimating standard wage equations, with log hourly wages as the dependent variable, and human capital variables (education and work experience) as well as job and labour market characteristics as explanatory variables. The size and nature of the wage 
differential is decomposed using the Oaxaca-Blinder decomposition technique to establish how much of the wage gap can be explained by differences in the observable characteristics of part-time and full-time workers, and what portion is "unexplained", reflecting differences in the returns to characteristics and in the intercept of the earnings functions.

In most countries, a wage penalty to part-time employment is observed, in the order of between $10 \%$ and $30 \%$. When estimations take into account that part-time workers may have less education and work experience, and may be concentrated in certain kinds of jobs, the size of the penalty falls but typically remains negative. Two exceptions are Sweden and Norway where the adjusted wage differential is positive, a finding attributed to low levels of wage dispersion and protective labour legislation in these labour markets (Bardasi and Gornick, 2002; Hardoy and Schøne, 2006).

Part-time and full-time workers may differ not only in terms of measurable attributes but further on the basis of unobserved characteristics, such as motivation and commitment, which are also correlated with labour market outcomes. Most studies that estimate the part-time wage gap make use of cross-sectional data, and control for nonrandom selection into part-time employment by estimating two-stage Heckman selection models (Simpson, 1986; Bardasi and Gornick, 2000; Rodgers, 2004; Hardoy and Schøne, 2006). Selection controls are found to reduce, and sometimes eliminate, the wage penalty to part-time employment. One of the difficulties of the Heckman approach, however, is finding instruments that are correlated with part-time status but not with the wage for reliable identification of the selection equation.

Panel data techniques tend to be a preferred means in the micro-econometric literature more broadly, of controlling for selection on the basis of unobservable characteristics. For a study of the part-time wage gap, a within-transformation of the panel data would remove the time-invariant component of the composite error term in the wage regression, and the estimation would test the effect of a change in part-time status on a change in log hourly wages. Only a few studies, however, have analysed the part-time wage gap using longitudinal data (see, for example, Hirsch, 2004). To our knowledge, there is also no research on part-time employment and wages in South Africa (whether based on cross-sectional or panel data). This study seeks to address this lacuna, making use also of the first national panel data set, recently made available to researchers, in South Africa.

\section{DATA AND DESCRIPTIVE STATISTICS}

\section{(a) Data and definitions}

We analyse both cross-sectional and panel household survey data to explore part-time employment in South Africa. To measure the growth in part-time employment from 1995 to 2004, we use the nationally representative October Household Surveys (OHS) conducted in 1995 and 1999 and selected September Labour Force Surveys (LFS) introduced in 2000 .

To compare the characteristics and returns to part-time and full-time female employment, we start with the September 2003 LFS (LFS, 2003:2), which collects comprehensive labour market information, including information on employment benefits. Although the LFSs are released as cross-sectional data sets, the survey has been designed as a rotating panel of dwellings, with a $20 \%$ rotation of the sample in each six 
monthly wave. To estimate earnings equations controlling for individual fixed effects, ${ }^{1}$ we use the LFS Panel (2001-2004) pre-released by Statistics South Africa (StatsSA) in January 2007. The unit of analysis of the panel is the individual and because individuals cannot be linked to their households, there are no household-level variables (such as number of children) which can be used in the analysis. The panel data set made available to researchers also contains a smaller set of information on employment benefits. Although the period of the panel is relatively short, approximately $8 \%$ of our sample changed between part-time and full-time status over the period (amounting to about 2,500 switchers).

There appears to be no formal (statistical or statutory) definition of part-time employment in South Africa. StatsSA has adopted different working-hour thresholds in different surveys. In the Survey of Total Employment and Earnings, for example, parttime employment is defined as normally working "less than 35 hours per week". In the Quarterly Employment Statistics, part-time employees are defined as "those... who usually work less than 40 hours per week". Although minimum wage determinations, which we discuss below, may distinguish different wage schedules for those working less than 28 hours a week, this threshold is not identified legally as defining part-time employment.

Internationally, the definition of part-time work differs across countries, but the convention seems to be fewer than 35 or 30 hours a week. For example, surveys in both the United Kingdom and Canada typically use 30 hours as the cut-off, while most surveys in the United States define part-time workers as those who usually work less than 35 hours a week (Hirsch, 2004; Hardoy and Schøne, 2006). Some surveys ask individuals directly to identify whether their employment is full-time or part-time and studies may adopt this self-definition of part-time employment rather than a fixed threshold (cf. Bardasi and Gornick, 2002).

Self-definition is not available in the surveys we use for South Africa and we therefore distinguish full-time and part-time employment according to the number of weekly hours worked. Figure 1, which plots the kernel density of usual weekly working hours in wage employment in 2003, shows a large spike at 40 hours, and a smaller one at 35 hours. For purposes of comparability with international studies, we use 35 hours a week as the cut-off defining full-time employment, but as we show later, our empirical findings on earnings differences are robust to alternative thresholds at 40 or 28 weekly working hours.

\section{(b) Describing female wage employment}

Over the past decade, much of the increase in employment in South Africa has reflected the growth in female employment (Casale and Posel, 2002; Casale, 2004). Table 1 describes trends in employment from 1995 to 2004 for salaried workers (i.e. excluding the self-employed).

Total wage employment grew by some 1.3 million jobs over the period, with almost $90 \%$ of this increase deriving from the change in female employment. In 1995, 35\% of all those with wage employment were women; by 2004, this had risen to $41 \%$. Over the same period, part-time wage employment increased by just over 200,000 jobs, almost all of which is accounted for by the rise in female part-time employment. Although from a

\footnotetext{
${ }^{1}$ As in many other studies, our ability to control for unobservable characteristics using a Heckman-type estimation method was hindered by the lack of appropriate instruments in the LFS 2003:2.
} 


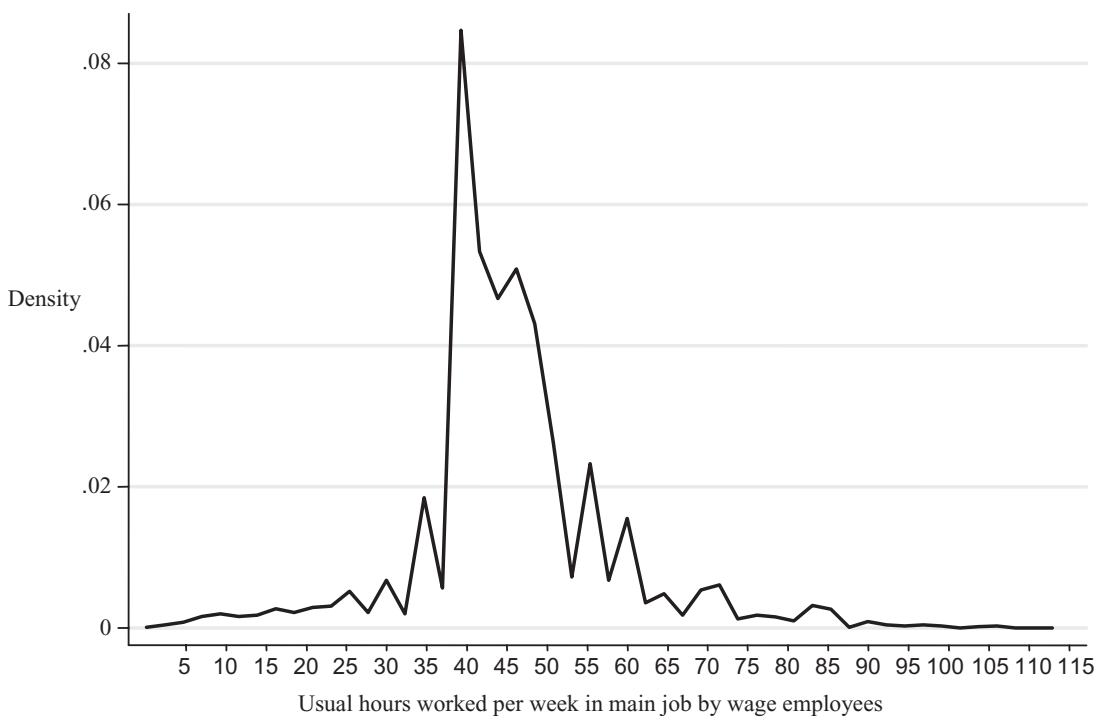

Figure 1. Kernel density plot of usual working hours in wage employment, 2003 Source: LFS 2003:2

Note: Epanechnikov kernel with unweighted data.

Table 1. Changes in wage employment by gender in South Africa

\begin{tabular}{llllll}
\hline & $\mathbf{1 9 9 5}$ & $\mathbf{1 9 9 9}$ & $\mathbf{2 0 0 1}$ & $\mathbf{2 0 0 3}$ & $\mathbf{2 0 0 4}$ \\
Total female wage employment & 2,829 & 3,662 & 3,830 & 3,914 & 3,947 \\
& $(29)$ & $(37)$ & $(48)$ & $(49)$ & $(56)$ \\
Female part-time wage employment & 279 & 503 & 506 & 520 & 479 \\
& $(10)$ & $(16)$ & $(20)$ & $(19)$ & $(20)$ \\
Proportion of part-time wage employed who are women & 51.5 & 62.5 & 64.0 & 65.9 & 64.0 \\
& $(1.3)$ & $(1.2)$ & $(1.5)$ & $(1.5)$ & $(1.7)$ \\
Proportion of employed women who work part-time & 9.9 & 13.7 & 13.2 & 13.4 & 12.1 \\
& $(0.3)$ & $(0.4)$ & $(0.5)$ & $(0.5)$ & $(0.5)$ \\
Total male wage employment & 5,325 & 5,033 & 5,351 & 5,510 & 5.579 \\
& $(36)$ & $(42)$ & $(55)$ & $(60)$ & $(67)$ \\
Male part-time wage employment & 263 & 301 & 284 & 269 & 269 \\
& $(10)$ & $(13)$ & $(14)$ & $(15)$ & $(16)$ \\
Proportion of employed men who work part-time & 4.9 & 6.0 & 5.3 & 4.9 & 4.8 \\
& $(0.2)$ & $(0.2)$ & $(0.3)$ & $(0.3)$ & $(0.3)$ \\
\hline
\end{tabular}

Source: OHS 1995 and 1999; LFS 2001:2; LFS 2003:2; LFS 2004:2.

Notes: The data are weighted and counts are in thousands. Standard errors are in parentheses. All employment estimates (total and part-time) are for individuals older than 15 years with wage employment, who reported non-zero working hours of less than 113 hours a week and for whom earnings information is not missing. Individuals have part-time wage employment if the number of hours usually worked in their main job is less than 35 hours a week. In 1995 only actual hours worked are available.

low base, the growth in female part-time employment greatly exceeded that in total female wage employment, and consequently the proportion of employed women who work part-time increased, from $9.9 \%$ in 1995 to $12.1 \%$ in 2004 . In contrast, male part-time employment remained relatively constant over the period, accounting for about $5 \%$ of total male wage employment.

There are clear differences in the measurable characteristics of women with part-time and full-time wage employment. We illustrate these differences using the LFS 2003:2. 
Table 2. Characteristics of female part-time and full-time wage employed, 2003

\begin{tabular}{lcc}
\hline & Part-time & Full-time \\
Mean age & $38.93^{*}$ & 37.01 \\
& $(0.43)$ & $(0.17)$ \\
Older than 59 years & 0.03 & 0.02 \\
& $(0.01)$ & $(0.00)$ \\
Years of education & $8.53^{*}$ & 9.87 \\
& $(0.16)$ & $(0.06)$ \\
Matric or equivalent & $0.19^{*}$ & 0.29 \\
& $(0.01)$ & $(0.01)$ \\
Postsecondary education & $0.15^{*}$ & 0.20 \\
& $(0.01)$ & $(0.01)$ \\
Married or living together & 0.50 & 0.49 \\
& $(0.01)$ & $(0.01)$ \\
Widowed or divorced & 0.15 & 0.14 \\
& $(0.01)$ & $(0.00)$ \\
Never married & 0.35 & 0.37 \\
White & $(0.02)$ & $(0.01)$ \\
& 0.14 & 0.17 \\
African & $(0.01)$ & $(0.01)$ \\
Urban & 0.68 & 0.64 \\
& $(0.02)$ & $(0.01)$ \\
Children $<7$ years & $0.65^{*}$ & 0.73 \\
& $(0.01)$ & $(0.01)$ \\
Children 7-14 years & 0.71 & 0.61 \\
& $(0.04)$ & $(0.01)$ \\
\hline Source & $0.81^{*}$ & 0.67 \\
& $(0.04)$ & $(0.01)$ \\
\hline
\end{tabular}

Source: LFS 2003:2

Notes: The sample is restricted to women older than 15 years with wage employment, who reported non-zero working hours of less than 113 hours a week and for whom earnings information is not missing. The data are weighted. Standard errors are in parentheses. * Means for part-time and full-time workers are significantly different at a $95 \%$ confidence level.

Table 2 shows that female part-time workers tend to be older and to have significantly lower levels of educational attainment on average than female full-time workers. Women who work part-time are also more likely to be living with children in the household suggesting greater non-market demands on their time.

Figure 2 reveals marked differences also in the characteristics of part-time and fulltime female wage employment by sector and occupational category. Part-time employment is over-represented in the informal sector: more than half of all women working part-time are employed in unregistered businesses, compared with less than $30 \%$ of women with full-time employment. Part-time employment clearly predominates in domestic services which accounts for almost $50 \%$ of all female part-time wage employment.

The Basic Conditions of Employment Act (BCEA) of 1997 provides a minimum standard of rights and protection for all the employed in South Africa who work at least 24 hours a month with a single employer (Department of Labour, 1997). The BCEA, which entitles workers to paid leave, a written contract with employers and notice prior to dismissal, was recently extended to cover domestic workers (Department of Labour 2002). Research suggests that although there has been some improvement in the terms of employment for domestic workers since 2002, compliance among employers remains low (Hertz, 2005). 


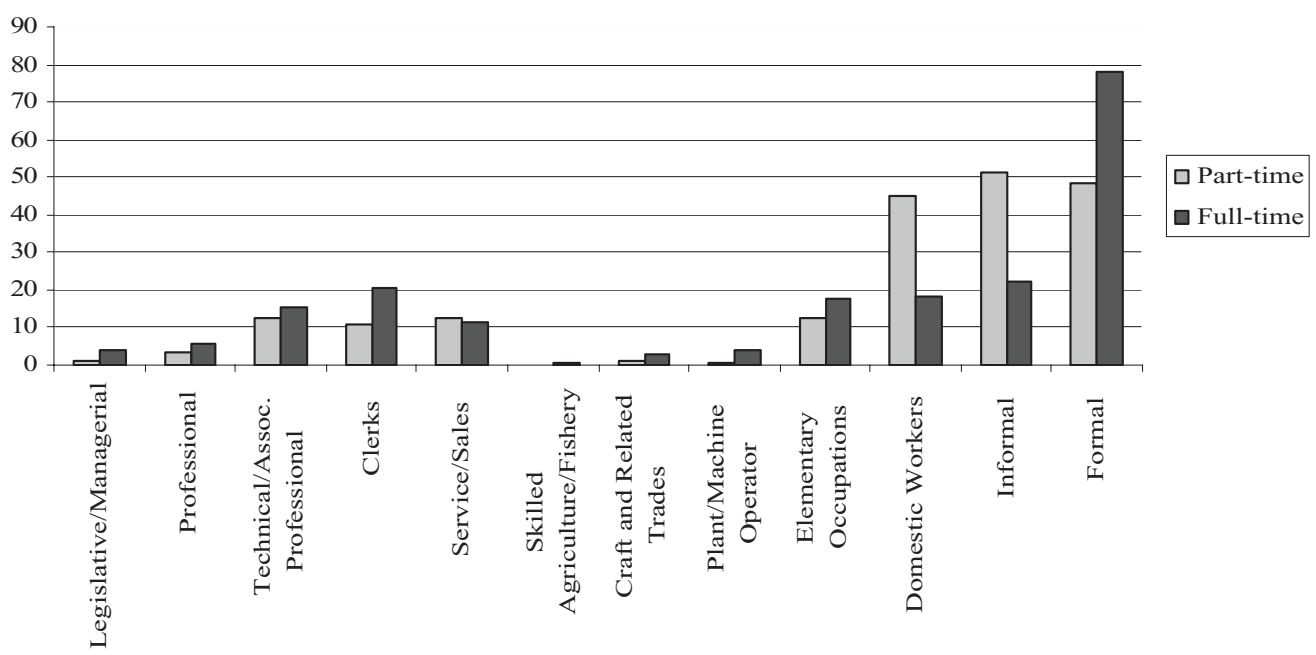

Figure 2. Distribution of female wage employment by occupation and sector, 2003 Source: LFS 2003:2. Note: The data are weighted.

Table 3 describes very large differences in the conditions of employment for part-time and full-time work. ${ }^{2}$ Women who work part-time are significantly less likely to have permanent employment or to receive any benefits (such as pension, unemployment or medical aid contributions from employers, or paid leave), and a significantly smaller percentage reports being union members. Conditions of employment among domestic workers are inferior to those for workers overall. Furthermore, among domestic workers, women with part-time employment receive significantly lower non-wage benefits compared with women with full-time employment.

Although there is no national minimum wage in South Africa, the BCEA also permits the Minister of Labour to determine minimum wages for employees by sector (Department of Labour, 1997). Minimum wage determinations are now in place in the domestic services, contract cleaning, private security, wholesale and retail trade, agricultural, civil engineering, forestry, hospitality, and taxi sectors. Minimum wages stipulated vary by sector; and within sector, by location of work and often by occupation.

In some sectors, higher minimum hourly wages are specified for those with lower working hours. In the domestic services sector, for example, employees who work less than 28 hours a week are entitled to an hourly wage which is approximately $10 \%$ higher than that earned by employees working longer hours (Department of Labour, 2002). In the wholesale and retail sector, the minimum hourly wage for individuals working fewer than 28 hours a week can be $25 \%$ higher than the relevant hourly wage specified in the sectoral determination for their occupation (Department of Labour, 2003). A possible motivation for these higher hourly wages may be to offset the lower level of benefits received by those working fewer hours a week.

In Table 4 we describe average wages and hours worked for women with wage employment in 2003. Although average hourly wages for women employed full-time

${ }^{2}$ We include here conditions which are not regulated by the BCEA - medical insurance, pension fund contributions and collective rights of workers. 
Table 3. Conditions of employment, 2003

\begin{tabular}{lcc}
\hline Proportion of all workers & Part-time & Full-time \\
Work is temporary or casual & $0.51^{*}$ & 0.17 \\
& $(0.02)$ & $(0.01)$ \\
Receive pension fund contribution & $0.21^{*}$ & 0.52 \\
& $(0.02)$ & $(0.01)$ \\
Receive medical insurance contribution & $0.12^{*}$ & 0.33 \\
& $(0.01)$ & $(0.01)$ \\
Receive paid leave & $0.29^{*}$ & 0.62 \\
& $(0.02)$ & $(0.01)$ \\
UIF contribution & $0.36^{*}$ & 0.64 \\
& $(0.02)$ & $(0.01)$ \\
Member of a trade union & $0.12^{*}$ & 0.29 \\
& $(0.01)$ & $(0.01)$ \\
Domestic workers & & \\
Work is temporary or casual & $0.59^{*}$ & 0.36 \\
Receive pension fund contribution & $(0.03)$ & $(0.02)$ \\
& $0.06^{*}$ & 0.11 \\
Receive medical insurance contribution & $(0.01)$ & $(0.01)$ \\
& 0.01 & 0.01 \\
Receive paid leave & $(0.00)$ & $(0.00)$ \\
UIF contribution & $0.14^{*}$ & 0.25 \\
& $(0.22)$ & $(0.02)$ \\
Member of a trade union & $0.21^{*}$ & 0.32 \\
& $(0.02)$ & $(0.02)$ \\
& $0.01^{*}$ & 0.02 \\
Source: & $(0.01)$ & $(0.00)$ \\
\hline
\end{tabular}

Source: LFS 2003:2

Notes: The sample is restricted to women older than 15 years with wage employment, who reported non-zero working hours of less than 113 hours a week and for whom earnings information is not missing. The data are weighted. Standard errors are in parentheses. ${ }^{*}$ Means for part-time and full-time workers are significantly different at a $95 \%$ confidence level.

Table 4. Average wages (rands) and working hours for parttime and full-time female employment, 2003

\begin{tabular}{lcc}
\hline & Part-time & Full-time \\
Reported (LFS 2003:2) & & \\
Monthly wage & 1351.49 & 2987.01 \\
& $(77.10)$ & $(69.81)$ \\
Hours worked & 21.84 & 45.99 \\
& $(0.31)$ & $(0.14)$ \\
Hourly wages & 14.80 & 15.96 \\
& $(0.81)$ & $(0.37)$ \\
Minimum wage determinations & & \\
Domestic work & & 4.42 \\
Clerk/shop assistant & 4.87 & 9.39 \\
\hline
\end{tabular}

Source: LFS 2003:2; Department of Labour (2002 and 2003).

Notes: 1. The sample of reported earnings is restricted to women older than 15 years with wage employment, who reported nonzero working hours of less than 113 hours a week and for whom earnings information is not missing. The data are weighted. 2. Wages are for those employed in metropolitan areas in South Africa.

are higher than for women employed part-time, the difference is not significant. The table illustrates also that minimum wage determinations by sector were relatively low compared with average hourly wages reported for both full-time and part-time employment. 


\section{ESTIMATING WAGE DIFFERENCES}

\section{(a) Econometric framework}

To explore wage differences between part-time and full-time employment in South Africa, we first use Ordinary Least Squares (OLS) to estimate two separate wage regressions for women who work part-time and full-time:

$$
\begin{aligned}
& \ln \left(W_{i}^{P}\right)=\alpha^{P}+\beta X_{i}^{P}+\varepsilon_{i} \\
& \ln \left(W_{i}^{F}\right)=\alpha^{F}+\beta X_{i}^{F}+\varepsilon_{i}
\end{aligned}
$$

where $W_{i}$ represents hourly wages of individual $i, X_{i}$ is a vector of individual, job and industry parameters, and $\varepsilon_{i}$ is the error term.

We then decompose the part-time/full-time average wage differential, using the standard Oaxaca-Blinder decomposition technique:

$$
\overline{\ln \left(W^{F}\right)}-\overline{\ln \left(W^{P}\right)}=\sum_{i} \beta^{F}\left(\bar{X}_{i}^{F}-\bar{X}_{i}^{P}\right)+\left\{\left(\hat{\alpha}^{F}-\hat{\alpha}^{P}\right)+\sum_{i} \bar{X}_{i}^{P}\left(\hat{\beta}^{F}-\hat{\beta}^{P}\right)\right\}
$$

The first term on the right-hand side of equation (3) represents the portion of the average wage differential that can be explained by differences in the observable characteristics of the two samples. The remaining terms reflect the "unexplained" part of the wage differential, captured by differences both in intercepts of the two wage equations and in the estimated coefficients (or returns to observable characteristics).

Coefficients estimated in the cross-sectional regressions, however, may be biased by individual fixed effects. If women who would do better in the labour market are also selected into full-time employment, for example, then the returns to individual endowments of full-time workers will be biased upwards. To estimate the effects of unmeasured characteristics on the estimated coefficients, we make use of panel data. We pool the six waves of the Labour Force Panel (LFS) to provide a benchmark for comparison, estimating:

$$
\ln \left(W_{i t}\right)=\alpha+\varphi P_{i t}+\beta X_{i t}+\delta_{i}+v_{i t}
$$

where $P_{i t}$ is a dummy-variable equal to 1 if individual $i$ had part-time employment in time $t$, and 0 if employment in that period was full-time. The composite error term comprises the time-invariant component $\delta_{i}$, representing individual-specific characteristics, and the time-varying, or idiosyncratic, component $v_{i t}$. To remove $\delta_{i}$ we estimate the fixed effects transformation:

$$
\ln \left(W_{i t}\right)-\ln \left(W_{i}\right)=\varphi^{F E}\left(P_{i t}-P_{i}\right)+\beta^{F E}\left(X_{i t}-X_{i}\right)+v_{i t}-v_{i}
$$

where for any variable $Z, Z_{i}$ represents the mean value for individual $i$ over the $t$ periods in the panel.

\section{(b) Results}

The results of our OLS estimations of wage equations for women with part-time and full-time employment are reported in Table 5. Two sets of estimations for 2003 are described: the first set includes individual, job, locational, industry, and household 
Table 5. Estimating the part-timelfull-time wage differential for women, 2003

\begin{tabular}{|c|c|c|c|c|}
\hline & Part-time & Full-time & Part-time & Full-time \\
\hline Age & $\begin{array}{l}0.019 \\
(0.012)\end{array}$ & $\begin{array}{l}0.022^{*} \\
(0.004)\end{array}$ & $\begin{array}{l}0.021^{* * *} \\
(0.012)\end{array}$ & $\begin{array}{l}0.020^{*} \\
(0.004)\end{array}$ \\
\hline Age2 & $\begin{array}{l}-0.000^{* * *} \\
(0.000)\end{array}$ & $\begin{array}{l}-0.000^{*} \\
(0.000)\end{array}$ & $\begin{array}{l}-0.000^{* *} \\
(0.000)\end{array}$ & $\begin{array}{l}-0.000^{*} \\
(0.000)\end{array}$ \\
\hline Primary education & $\begin{array}{l}0.123^{* * *} \\
(0.065)\end{array}$ & $\begin{array}{l}0.112^{*} \\
(0.030)\end{array}$ & $\begin{array}{l}0.147^{* *} \\
(0.066)\end{array}$ & $\begin{array}{l}0.099^{* * *} \\
(0.030)\end{array}$ \\
\hline Incomplete secondary & $\begin{array}{l}0.292^{*} \\
(0.072)\end{array}$ & $\begin{array}{l}0.246^{*} \\
(0.032)\end{array}$ & $\begin{array}{l}0.312^{*} \\
(0.074)\end{array}$ & $\begin{array}{l}0.219^{*} \\
(0.032)\end{array}$ \\
\hline Matric & $\begin{array}{l}0.452^{*} \\
(0.105)\end{array}$ & $\begin{array}{l}0.455^{*} \\
(0.037)\end{array}$ & $\begin{array}{l}0.432^{*} \\
(0.103)\end{array}$ & $\begin{array}{l}0.385^{*} \\
(0.037)\end{array}$ \\
\hline Post-matric & $\begin{array}{l}0.870^{*} \\
(0.136)\end{array}$ & $\begin{array}{l}0.757^{*} \\
(0.045)\end{array}$ & $\begin{array}{l}0.829^{*} \\
(0.132)\end{array}$ & $\begin{array}{l}0.634^{*} \\
(0.045)\end{array}$ \\
\hline Married/cohabiting & $\begin{array}{l}0.034 \\
(0.053)\end{array}$ & $\begin{array}{l}0.048^{*} \\
(0.017)\end{array}$ & $\begin{array}{l}0.021 \\
(0.052)\end{array}$ & $\begin{array}{l}0.047^{*} \\
(0.016)\end{array}$ \\
\hline Previously married & $\begin{array}{l}0.096 \\
(0.068)\end{array}$ & $\begin{array}{l}0.081^{*} \\
(0.023)\end{array}$ & $\begin{array}{l}0.080 \\
(0.069)\end{array}$ & $\begin{array}{l}0.070^{*} \\
(0.022)\end{array}$ \\
\hline Urban area & $\begin{array}{l}0.254^{*} \\
(0.051)\end{array}$ & $\begin{array}{l}0.224^{*} \\
(0.020)\end{array}$ & $\begin{array}{l}0.234^{*} \\
(0.051)\end{array}$ & $\begin{array}{l}0.177^{*} \\
(0.019)\end{array}$ \\
\hline Formal sector & $\begin{array}{l}0.312^{*} \\
(0.105)\end{array}$ & $\begin{array}{l}0.412^{*} \\
(0.040)\end{array}$ & $\begin{array}{l}0.277^{*} \\
(0.103)\end{array}$ & $\begin{array}{l}0.298^{*} \\
(0.038)\end{array}$ \\
\hline Large firm & $\begin{array}{l}-0.035 \\
(0.085)\end{array}$ & $\begin{array}{l}0.077^{*} \\
(0.019)\end{array}$ & $\begin{array}{l}-0.037 \\
(0.081)\end{array}$ & $\begin{array}{l}0.027 \\
(0.018)\end{array}$ \\
\hline Union member & $\begin{array}{l}0.326^{*} \\
(0.097)\end{array}$ & $\begin{array}{l}0.309^{*} \\
(0.020)\end{array}$ & $\begin{array}{l}0.128 \\
(0.097)\end{array}$ & $\begin{array}{l}0.142^{*} \\
(0.020)\end{array}$ \\
\hline Length of current tenure & $\begin{array}{l}0.016^{* * *} \\
(0.009)\end{array}$ & $\begin{array}{l}0.036^{*} \\
(0.003)\end{array}$ & $\begin{array}{l}0.011 \\
(0.009)\end{array}$ & $\begin{array}{l}0.020^{*} \\
(0.003)\end{array}$ \\
\hline (Length of current tenure) 2 & $\begin{array}{l}-0.000 \\
(0.000)\end{array}$ & $\begin{array}{l}-0.000^{*} \\
(0.000)\end{array}$ & $\begin{array}{l}-0.000 \\
(0.000)\end{array}$ & $\begin{array}{l}-0.000^{*} \\
(0.000)\end{array}$ \\
\hline Permanent employment & - & - & $\begin{array}{l}-0.077 \\
(0.055)\end{array}$ & $\begin{array}{l}0.064^{*} \\
(0.021)\end{array}$ \\
\hline Medical aid contribution & - & - & $\begin{array}{l}0.327^{*} \\
(0.093)\end{array}$ & $\begin{array}{l}0.271^{*} \\
(0.021)\end{array}$ \\
\hline UIF contribution & - & - & $\begin{array}{l}0.006 \\
(0.048)\end{array}$ & $\begin{array}{l}0.059^{*} \\
(0.017)\end{array}$ \\
\hline Pension contribution & - & - & $\begin{array}{l}0.140^{* * *} \\
(0.075)\end{array}$ & $\begin{array}{l}0.242^{*} \\
(0.021)\end{array}$ \\
\hline Paid leave & - & - & $\begin{array}{l}0.152^{* *} \\
(0.064)\end{array}$ & $\begin{array}{l}0.172^{*} \\
(0.019)\end{array}$ \\
\hline Constant & $\begin{array}{l}1.382^{*} \\
(0.365)\end{array}$ & $\begin{array}{l}0.679^{*} \\
(0.112)\end{array}$ & $\begin{array}{l}1.388^{*} \\
(0.370)\end{array}$ & $\begin{array}{l}0.713^{*} \\
(0.107)\end{array}$ \\
\hline $\begin{array}{l}\text { Number of observations } \\
\mathrm{R}^{2}\end{array}$ & $\begin{array}{l}1,064 \\
0.62\end{array}$ & $\begin{array}{l}6,865 \\
0.74\end{array}$ & $\begin{array}{l}1,035 \\
0.65\end{array}$ & $\begin{array}{l}6,661 \\
0.77\end{array}$ \\
\hline $\begin{array}{l}\text { Total (unadjusted) differential } \\
\text { Endowments } \\
\text { Coefficients } \\
\text { Constant } \\
\text { Adjusted differential } \\
\end{array}$ & $\begin{array}{l}-2.9 \\
-37.0 \\
-36.2 \\
70.3 \\
34.1 \\
\end{array}$ & & $\begin{array}{l}-3.6 \\
-43.8 \\
-27.3 \\
67.5 \\
40.2 \\
\end{array}$ & \\
\hline
\end{tabular}

Source: LFS 2003:2

Notes: The data are not weighted. Robust standard errors are in parentheses. The omitted education category is "no schooling". The regressions also control for population group, number of children in the household, province of residence, 9 occupation dummies (including domestic work as a separate occupational category) and 11 industry dummies. ${ }^{* * *}$ Significant at $10 \%$ ** Significant at $5 \%$ * Significant at $1 \%$. Note that in the decomposition analysis, the negative sign indicates an advantage to full-time workers.

characteristics as controls; in the second set, variables capturing conditions of employment are added.

The unadjusted wage differential is small and negative, implying a "raw" wage penalty to part-time employment of between $3 \%$ and $4 \%$. Women who work full-time, however, have a significant advantage in individual and job characteristics over part-time workers. When we adjust for differences in endowments, the wage penalty to part-time 
employment becomes positive, indicating an hourly wage premium to working part-time of about $34 \%$, or $40 \%$ when we control also for working conditions. ${ }^{3}$ The source of this premium derives from the shift coefficient. Although full-time workers receive significantly higher returns to endowments, this is more than offset by a considerably larger constant for those with part-time employment.

A key concern with OLS estimations of wage equations for different groups of workers is that omitted variables, such as unmeasured labour market skills and motivation, may produce biased and inconsistent coefficients. Studies of wage differentials between parttime and full-time employment typically have found a significant penalty to part-time employment. If there is negative selection into part-time employment, then the estimated penalty would be overstated. In the case of a wage premium to part-time employment, however, we would expect bias in the other direction. If part-time workers have "inferior" unobserved characteristics, then controlling for these unobservables should increase the size of the premium.

We investigate this, also as a way of testing the robustness of our results, in the fixed effects estimations reported in Table 6 . The first column reports the estimated coefficients when we ignore the panel structure of the data and simply pool the waves of the LFS Panel (2001-2004). Consistent with our cross-sectional results for the LFS 2003:2, we find a large and positive premium to female part-time employment in the pooled regression, after controlling for a wide range of observable characteristics. The second column reports the fixed effects estimates for the time-demeaned panel data. As expected, the size of the coefficient on part-time employment increases when we estimate the within transformation, suggesting negative correlation between unobserved effects and part-time employment status. ${ }^{4,5}$

Our results are suggestive of a "wage floor" in part-time employment, possibly created by minimum wages, below which wages cannot drop. We tested the robustness of these results to different definitions of part-time employment, raising the threshold to 40 hours a week, and lowering it to 28 hours. The pooled OLS and fixed effects coefficients for part-time employment (controlling for all other characteristics) are reported in Table 7. The premium to part-time employment remains robust and large for all definitions. Furthermore, the size of the premium increases considerably when the threshold defining part-time status is lowered, a result consistent with minimum wage determinations which specify higher hourly wages for those working fewer than 28 hours a week.

There are a number of sources of bias that may confound this comparison of part-time and full-time wages. Information on hourly wages is not collected directly in our datasets and we use working hours to convert weekly or monthly wages into hourly figures. Our hourly wage estimates therefore are vulnerable to problems caused by division bias (Manning and Robinson, 2004). If full-time and part-time workers overstate and understate their working hours, respectively, then hourly wages for full-time employment will be deflated while those for part-time employment will be inflated.

\footnotetext{
3 There is a similar premium to female part-time employment (of between 33\% and 40\%) also for a restricted sample that excludes all domestic workers.

${ }^{4}$ In contrast, the positive coefficients for formal employment, union status and currently or previously married all fall when we control for individual fixed effects.

5 A Hausman test of systematic differences in the coefficients between a random and a fixed effects model generated a $\chi^{2}$ of $3,835.28$, suggesting that the fixed effects estimator is more appropriate.
} 
Table 6. Wage estimations for female employment, 20012004

\begin{tabular}{|c|c|c|}
\hline & Pooled & Fixed effects \\
\hline Part-time employment & $\begin{array}{c}0.441^{*} \\
(0.012)\end{array}$ & $\begin{array}{c}0.464^{*} \\
(0.014)\end{array}$ \\
\hline Age & $\begin{array}{c}0.019^{*} \\
(0.003)\end{array}$ & - \\
\hline Age2 & $\begin{array}{r}-0.172^{*} \\
(0.031)\end{array}$ & - \\
\hline Primary education & $\begin{array}{l}0.112^{*} \\
(0.016)\end{array}$ & - \\
\hline Incomplete secondary & $\begin{array}{c}0.278^{*} \\
(0.016)\end{array}$ & - \\
\hline Matric & $\begin{array}{c}0.445^{*} \\
(0.019)\end{array}$ & - \\
\hline Post-matric & $\begin{array}{c}0.741^{*} \\
(0.022)\end{array}$ & - \\
\hline Married/cohabiting & $\begin{array}{c}0.045^{*} \\
(0.009)\end{array}$ & $\begin{array}{c}0.035 \\
(0.027)\end{array}$ \\
\hline Previously married & $\begin{array}{c}0.065^{*} \\
(0.012)\end{array}$ & $\begin{array}{c}0.013 \\
(0.028)\end{array}$ \\
\hline Metropolitan area & $\begin{array}{c}0.204^{*} \\
(0.010)\end{array}$ & - \\
\hline Formal sector & $\begin{array}{c}0.261^{*} \\
(0.020)\end{array}$ & $\begin{array}{c}0.093^{*} \\
(0.022)\end{array}$ \\
\hline Large firm & $\begin{array}{c}0.066^{*} \\
(0.009)\end{array}$ & $\begin{array}{c}0.023^{* *} \\
(0.012)\end{array}$ \\
\hline Union member & $\begin{array}{c}0.223^{*} \\
(0.010)\end{array}$ & $\begin{array}{c}0.067^{*} \\
(0.012)\end{array}$ \\
\hline Length of current tenure & $\begin{array}{c}0.024^{*} \\
(0.002)\end{array}$ & $\begin{array}{c}0.009^{*} \\
(0.002)\end{array}$ \\
\hline (Length of current tenure) 2 & $\begin{array}{c}-0.001^{*} \\
(0.0001)\end{array}$ & $\begin{array}{r}-0.0002^{* *} \\
(0.00006)\end{array}$ \\
\hline Permanent employment & $\begin{array}{c}0.152^{*} \\
(0.010)\end{array}$ & $\begin{array}{c}0.082^{*} \\
(0.013)\end{array}$ \\
\hline Medical aid contribution & $\begin{array}{c}0.288^{*} \\
(0.011)\end{array}$ & $\begin{array}{c}0.075^{*} \\
(0.012)\end{array}$ \\
\hline UIF contribution & $\begin{array}{c}0.083^{*} \\
(0.009)\end{array}$ & $\begin{array}{c}0.036^{*} \\
(0.009)\end{array}$ \\
\hline $\mathrm{R}^{2}$ & 0.726 & 0.117 (within) \\
\hline
\end{tabular}

Source: LFS Panel (2001-2004)

Notes: The data are not weighted. Standard errors are in parentheses. In both regressions, the omitted marital status variable is "never married"; in the pooled regression, the omitted education category is "no schooling". The estimations also include 9 occupation, 11 industry and 6 wave dummies, not reported here; and the pooled estimation controlled further for province of residence. ${ }^{*}$ Significant at $1 \%{ }^{* *}$ Significant at 5\%.

Approximately $10 \%$ of our sample of female employees reported working sixty hours or more a week (25\% of whom were working eighty weekly hours or more). In Table 7 we also report the coefficients for part-time employment when we truncate our sample to the employed with 'credible' working hours. The premium declines when we remove outliers from the working-hours distribution, but it remains large and significant throughout. The premium is also robust when we compress rather than truncate the working-hours distribution. The last row in Table 7 reports the estimated coefficients for part-time employment when we inflate, or deflate, working hours by $20 \%$ for those working less than 20 hours a week, or more than 45 hours a week, respectively.

A remaining source of bias in the wage estimation derives from the possible endogeneity of part-time employment status. If higher wage growth induces employed 
Table 7. The estimated wage premium to female part-time employment with different definitions, samples and reduced controls

\begin{tabular}{|c|c|c|}
\hline & Pooled & Fixed effects \\
\hline $\begin{array}{l}\text { Redefining part-time employment } \\
\text { - less than } 40 \text { hours a week }\end{array}$ & $\begin{array}{r}0.376^{*} \\
(0.010)\end{array}$ & $\begin{array}{r}0.373^{*} \\
(0.011)\end{array}$ \\
\hline - less than 28 hours a week & $\begin{array}{c}0.565^{*} \\
(0.015)\end{array}$ & $\begin{array}{r}0.595^{*} \\
(0.017)\end{array}$ \\
\hline $\begin{array}{l}\text { Removing the tails of the weekly hours distribution } \\
- \text { less than } 80 \text { hours }^{1}\end{array}$ & $\begin{array}{c}0.426^{*} \\
(0.013)\end{array}$ & $\begin{array}{l}0.457^{*} \\
(0.014)\end{array}$ \\
\hline - less than 60 hours $^{2}$ & $\begin{array}{r}0.392^{*} \\
(0.013)\end{array}$ & $\begin{array}{c}0.437^{*} \\
(0.014)\end{array}$ \\
\hline - more than 20 and less than 60 hours $^{3}$ & $\begin{array}{l}0.227^{*} \\
(0.013)\end{array}$ & $\begin{array}{l}0.316^{*} \\
(0.015)\end{array}$ \\
\hline $\begin{array}{l}\text { Compressing the weekly hours distribution } \\
\text { - (less than } 20 \text { hours)*1.2 and (more than } 45 \text { hours) }{ }^{*} 0.8\end{array}$ & $\begin{array}{r}0.316^{*} \\
(0.012)\end{array}$ & $\begin{array}{r}0.371^{*} \\
(0.014)\end{array}$ \\
\hline
\end{tabular}

Source: LFS Panel (2001-2004)

Notes: From a total sample of 28,465 employed women in the pooled waves, the sample selections reduced the total sample by: 1. 646 observations; 2. 2,274 observation; and 3. 3,170 observations. Standard errors are in parentheses. The earnings estimations controlled for the full range of individual, job and industry characteristics. * Significant at $1 \%$.

women to work part-time (or if it induces employers to reduce working hours), then our estimations will overstate the premium to part-time employment, even after controlling for unobservable characteristics. There are no household level variables available in the LFS panel, however, and we can find no individual level instrumental variables, which are both exogenous to the wage equation and highly correlated with part-time employment status, with which to address this endogeneity.

\section{CONCLUSION}

In common with many other countries in the world, the majority of part-time workers in South Africa are women, and part-time employment forms a growing share of women's total wage employment. Female part-time employment is usually associated with a wage penalty that persists after controlling for individual, job and labour market characteristics. In contrast, we find no evidence of a wage penalty to female part-time employment in South Africa. Rather, our estimations indicate a wage premium to part-time employment which increases when we control for unobservable characteristics using fixed effects estimation with panel data. Our findings of a part-time premium remain robust to different working-hours thresholds defining part-time employment, and to controls for possible measurement error in reported hours worked.

Our results of a part-time wage premium are consistent with there being a wage floor below which wages for part-time workers cannot fall (regardless of worker and job characteristics). This wage floor could derive from minimum wage determinations, which are higher for those working fewer hours across a number of sectors, or given imperfect adherence to these determinations, from some minimum subsistence level. Part of the 
estimated premium may also serve to offset the significantly lower levels of security and non-wage benefits which characterise female part-time employment.

\section{REFERENCES}

BARDASI, E. and GORNICK, J. C. (2000). Women and part-time employment: Worker's 'choices' and wage penalties in five industrialised countries. Luxembourg Income Study Working Paper No. 223.

and - (2002). Explaining cross-national variation in part-time/full-time wage differentials among women. Paper prepared for the workshop on 'Comparative Political Economy of Inequality'. Cornell University, Ithaca, New York. April 5-7.

CASALE, D. and POSEL, D. (2002). The feminisation of the labour force in South Africa: an analysis of recent data and trends. The South African Journal of Economics, 70(1): 156-184.

(2004). What has the feminisation of the labour market 'bought' women in South Africa? Trends in labour force participation, employment and earnings, 1995-2001. The Journal of Interdisciplinary Economics, 15: 251-275.

DEPARTMENT OF LABOUR (1997). Basic Conditions of Employment Act. Government Gazette, 390: 18491, December.

(2002). Basic Conditions of Employment Act: Sectoral Determination 7: Domestic Services Sector. Government Gazette, 446: 23732, August.

(2003). Basic Conditions of Employment Act: Sectoral Determination 9: Wholesale and Retail Sector. Available from www.labour.gov.za/ legislation - accessed 27 July 2007.

ERMISCH, J. F. and WRIGHT, R. E. (1993). Wage offers and full-time and part-time employment by British women. The Journal of Human Resources, 25(1):111-133.

HARDOY, I. and SCHØNE, P. (2006). The part-time wage gap in Norway: How large is it really? British Journal of Industrial Relations, 44(2): 263-282.

HERTZ, T. (2005). The effect of minimum wages on the employment and earnings of South Africa's domestic services workers. Paper presented at the 2005 Annual Development Policy Research Unit, Cape Town.

HIRSCH, B. T. (2004). Why do part-time workers earn less? The role of worker and job skills. Institute for the Study of Labour (IZA) Discussion Paper No. 1261.

LABOUR FORCE PANEL (2001-2004). The Labour Force Panel. Pretoria: Statistics South Africa.

LFS (2003). The Labour Force Survey, September. Pretoria: Statistics South Africa.

LONG, J. E. and JONES, E. B. (1981). Married women in part-time employment. Industrial and Labour Relations Review, 34(3): 413-425.

MANNING, A. and ROBINSON, H. (2004). Something in the way she moves: A fresh look at an old gender gap. Oxford Economic Papers, 56: 169-188.

OWEN, J. D. (1978). Why part-time workers tend to be in low-wage jobs. Monthly Labour Review, 101(6):11-14.

OCTOBER HOUSEHOLD SURVEYS (1995-1999). The October Household Surveys. Pretoria: Statistics South Africa.

RODGERS, J. R. (2004). Hourly wages of full-time and part-time employees in Australia. Australian Journal of Labour Economics, 7: 215-238.

ROSENFELD, R. A. and BIRKELUND, G. E. (1995). Women's part-time work: A cross-national comparison. European Sociological Review, 11(2):111-134.

SIMPSON, W. (1986). Analysis of part-time pay in Canada. The Canadian Journal of Economics, 19(4):798-807. 